\title{
Effect of preparation conditions on the nanostructure of hydroxyapatite and brushite phases
}

\author{
S. F. Mansour ${ }^{1}$ - S. I. El-dek ${ }^{2}$ M. A. Ahmed ${ }^{3}$ - S. M. Abd-Elwahab ${ }^{3}$. \\ M. K. Ahmed ${ }^{3}$
}

Received: 9 September 2015/Accepted: 30 October 2015/Published online: 16 November 2015

(C) The Author(s) 2015. This article is published with open access at Springerlink.com

\begin{abstract}
Hydroxyapatite (HAP) and dicalcium phosphate dihydrate (brushite) nanoparticles were prepared by co-precipitation method. The obtained products were characterized by X-ray powder diffraction (XRD), Fourier transformation infra-red spectroscopy (FTIR) and thermogravimetric analysis (TGA). Scanning electron microscopy (SEM) and transmission electron microscope (TEM) were used to investigate the morphology of the powdered samples as well as their microstructure, respectively. Brushite samples were obtained in a spherical shape, while hydroxyapatite was formed in a needle and rice shape depending on the $\mathrm{pH}$ value.
\end{abstract}

Keywords Bioceramics $\cdot$ Brushite $\cdot$ Hydroxyapatite

\section{Introduction}

In the past few years, calcium phosphate-based materials have been used in many applications in bone regeneration and replacement, teeth pores filling, drug delivery, enhancement of bone growth and in tissue engineering due to their bioactivity and biocompatibility (Navarro et al. 2008; Viswanath and Ravishankar 2008; Rey et al. 2007).

S. I. El-dek

didi5550000@gmail.com

1 Physics Department, Faculty of Science, Zagazig University, Zagazig, Egypt

2 Materials Science and Nanotechnology Department, Faculty of Post Graduate Studies for Advanced Science, Beni-Suef University, Beni-Suef, Egypt

3 Materials Science Lab (1), Physics Department, Faculty of Science, Cairo University, Giza, Egypt
Different phases of calcium phosphate nanoparticles (CaP) with different sizes and shapes can be suitable for different purposes (Sørensen and Madsen 2000; Jadalannagari et al. 2011; Oliveira et al. 2007; Ahmed et al. 2008). Several researchers under different preparation conditions studied the synthesis of calcium phosphate extensively (Nilsson et al. 2002; Ren et al. 2012; Kundu et al. 2010a). By varying temperature, $\mathrm{pH}$ and initial reagent concentrations, one can obtain different calcium phosphate phases (Kundu et al. 2010b).

It is well known that, hydroxyapatite (HAP: $\mathrm{Ca}_{10}(-$ $\left.\mathrm{PO}_{4}\right)_{6}(\mathrm{OH})_{2}$ ) with a hexagonal crystal structure, is one member of the 'apatite' family (Tas 2000; Badraoui et al. 2009). In osteology, calcium is one of the most important inorganic ions, in addition to phosphate given the key component of the mineralized bone matrix. It has a central role in maintaining calcium homeostasis that is very essential for the normal physiological functions (Blair et al. 2007; Peacock 2010). Bone diseases arise when homeostasis is not maintained. Within bone matrix, calcium is important at the whole tissue level, both as a structural component of the mineralized matrix and as a signal transduction molecule for eliciting cellular responses. Owing to its closed structural resemblance to bones and teeth, HAP has attracted much attention as a substitute material for damaged teeth or bones over the last years (Suchanek and Yoshimura 1997; Hench 1991; Ohura et al. 1996).

Calcium hydrogen phosphate dihydrate (DCPD: $\mathrm{CaHPO}_{4} \cdot 2 \mathrm{H}_{2} \mathrm{O}$ ), known as brushite, can be used alone or combined with other materials in the regeneration of bone and various surgical sites in animal models, because it has the ability to be resorbed under physiological conditions (Tamimi et al. 2012; Hench 1998). Therefore, this study is important for bio-mineralization phenomena (Singh et al. 
2010). Brushite is also important as soil phosphate fertilizer; it is relatively water soluble as compared with HAP (Pattanayak et al. 2007). It can be used for supplying plant implants with the necessary amount of calcium phosphate (Singh et al. 2010). The physical properties of calcium phosphate ceramics vary strongly according to particle shape, particle size, distribution and agglomeration (Ferreira et al. 2003).

The objective of this work is the preparation of both brushite and hydroxyapatite nanoparticles by simple coprecipitation method to study deeply how the preparation conditions could represent crucial parameters to control calcium phosphate physico-chemical properties. Tuning the properties of such bioceramics could generally improve their use in different biomedical applications owing to their biodegradability, biocompatibility as mentioned above.

\section{Materials and methods}

All chemicals were of analytical grade form used without further purification. Disodium hydrogen phosphate $\left(\mathrm{Na}_{2}\right.$ $\mathrm{HPO}_{4}$, Merck) and calcium chloride $\left(\mathrm{CaCl}_{2} \cdot 2 \mathrm{H}_{2} \mathrm{O}\right.$, Merck) were used as the starting materials. A diluted solution of ammonium hydroxide $\left(\mathrm{NH}_{4} \mathrm{OH}\right.$, Merck) and $\mathrm{HCl}$ were used as adjusting reagents for $\mathrm{pH}$ values.

The flowchart of samples preparation is shown in Fig. 1. Two different groups of samples were prepared using the same procedure, namely co-precipitation method. The first one is concerned with the $\mathrm{Ca} / \mathrm{P}$ ratio $(1: 1)$ and $\mathrm{pH}$ values of 4, 5 and 6 adjusted using $\mathrm{NH}_{4} \mathrm{OH}$ and/or $\mathrm{HCl}$. The second group in which $\mathrm{Ca} / \mathrm{P}$ ratio is $(5: 3)$ and the $\mathrm{pH}$ values were adjusted at 7, 9 and 12 using $\mathrm{NH}_{4} \mathrm{OH}$ droplets.

The solutions in both cases were continuously stirred for $24 \mathrm{~h}$ (Table 1). The $\mathrm{pH}$ value of the suspension was continuously adjusted and maintained at the above-mentioned values during precipitation. The obtained solutions were placed in Teflon flasks and tightly sealed, then aged at room temperature for $24 \mathrm{~h}$ to allow precipitation. White precipitated powder was filtered thoroughly and washed several times with double distilled water and finally dried at $50-60{ }^{\circ} \mathrm{C}$ for $12 \mathrm{~h}$.

Powder X-ray diffraction analyses were carried out using (analytical- $x^{\prime}$ pertpro with $\mathrm{Cu} \mathrm{k}_{\alpha 1}$ target, $\lambda=1.5404$ $\AA, 45 \mathrm{kV}, 40 \mathrm{~mA}$, The Netherlands) to identify the phase composition and crystallinity of the calcium phosphate compounds. FT-IR spectrometer (Perkin-Elmer system 2000) was used for recording FTIR spectra in the range of $4000-400 \mathrm{~cm}^{-1}$. Thermo-gravimetric analysis (TGA) was carried out from room temperature up to $1200{ }^{\circ} \mathrm{C}$ in a DTG-60H SHIMADZU analyzer using an air flow rate of $100 \mathrm{~mL} / \mathrm{min}$ and a heating rate of $10^{\circ} \mathrm{C} / \mathrm{min}$. The surface morphology was studied using scanning electron

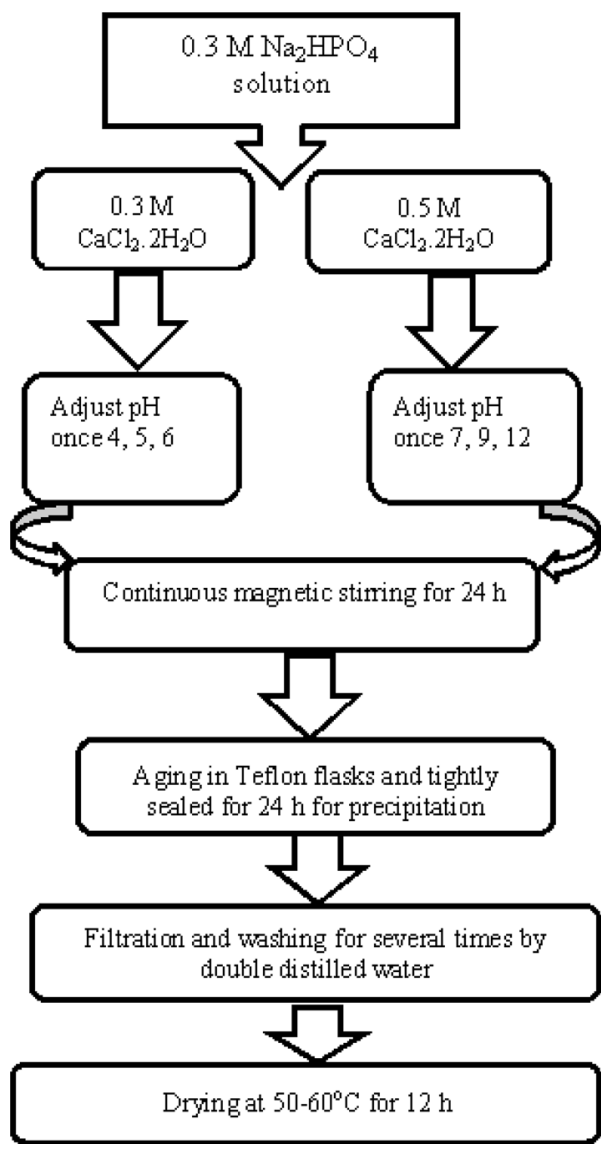

Fig. 1 Flowchart of prepared brushite and hydroxyapatite powder

Table 1 Values of $\mathrm{Ca} / \mathrm{P}, \mathrm{pH}$ values and compound after $24 \mathrm{~h}$ reaction time

\begin{tabular}{lcr}
\hline Compound & $\mathrm{Ca} / \mathrm{P}$ & $\mathrm{pH}$ \\
\hline DCPD & $1: 1$ & 5 \\
DCPD & $1: 1$ & 6 \\
HAP & $5: 3$ & 7 \\
HAP & $5: 3$ & 9 \\
HAP & $5: 3$ & 12 \\
\hline
\end{tabular}

microscope (SEM) model LEO-1530. The particle size and shape were investigated by transmission electron microscope (TEM) model JEOL/JME-2100.

\section{Results and discussion}

\section{Structural analysis}

\section{$X$-ray diffraction $(X R D)$}

The sample with low $\mathrm{pH}$ value 4 did not precipitate and was completely clear during the experiment. XRD patterns 

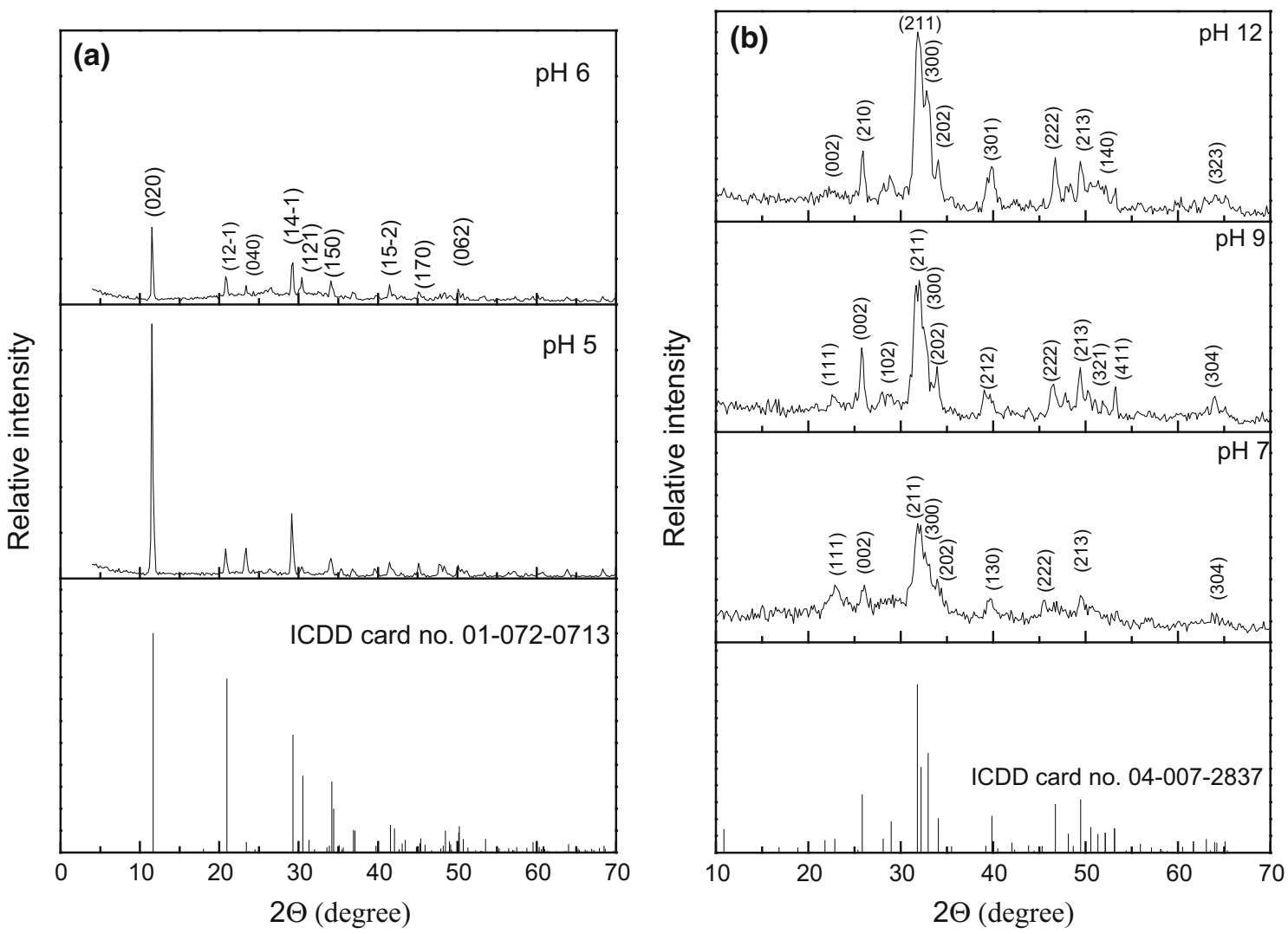

Fig. 2 a XRD pattern of calcium phosphate at $\mathrm{pH}$ 5, 6, b XRD pattern of calcium phosphate at pH 7, 9, 12

Table 2 Variation of crystallite size, particle size, shape, bulk density, theoretical density and relative porosity

\begin{tabular}{|c|c|c|c|c|c|c|c|}
\hline \multirow[t]{2}{*}{ Compound } & \multirow{2}{*}{$\begin{array}{l}\text { Crystallite size } \\
\text { (XRD) (nm) }\end{array}$} & \multicolumn{2}{|c|}{ Particle size (TEM) } & \multirow[t]{2}{*}{ Shape } & \multirow[t]{2}{*}{ Density $\left(\mathrm{g} / \mathrm{cm}^{3}\right)$} & \multirow{2}{*}{$\begin{array}{l}\text { Theoretical } \\
\text { density }\left(\mathrm{g} / \mathrm{cm}^{3}\right)\end{array}$} & \multirow[t]{2}{*}{ Porosity $\%$} \\
\hline & & Dia.(nm) & Length (nm) & & & & \\
\hline DCPD pH 5 & 55 & $50-90^{\mathrm{a}}$ & - & Sphere & 2.13 & 2.32 & 8.24 \\
\hline DCPD pH 6 & 41 & $5-10$ & $50-150$ & Fiber network & 1.75 & 2.32 & 24.71 \\
\hline HAP pH 7 & 5 & $5-10$ & $150-200$ & Needle & 1.54 & 3.23 & 53.58 \\
\hline HAP $\mathrm{pH} 9$ & 15 & $20-30$ & $200-300$ & Rods & 1.94 & 3.16 & 38.74 \\
\hline HAP pH 12 & 16 & $10-20$ & $40-60$ & Rice & 1.93 & 3.17 & 39.21 \\
\hline
\end{tabular}

a Spherical shape

for the samples of the first group synthesized at pH 5 and 6 represent brushite with single phase as shown in Fig. 2a and agree well with the ICDD card no. 01-072-0713. These patterns show that the peaks of brushite at $\mathrm{pH} 5$ have higher intensities than those at $\mathrm{pH} 6$. The crystallinity of these samples was found to decrease with increasing $\mathrm{pH}$ value as reported in Table 2.

Figure $2 b$ illustrates XRD patterns for the samples of the second group prepared at $\mathrm{pH}$ values 7, 9 and 12, which demonstrate that the $\mathrm{pH}$ value takes the upper hand in the formation of HAP. Phase analysis was identified using ICDD card no. 04-007-2837 for HAP. It is clearly noted that the sample with higher $\mathrm{pH}$ has sharper diffraction peaks (larger crystallite size) than other samples. These results indicate that $\mathrm{HAP}$ at $\mathrm{pH} 12$ has larger crystallite size as shown in Fig. 2b. The broad pattern of the samples was attributed to the formation of poor crystalline HAP, which leads to higher dissolution compared with well-crystallized HAP. Moreover, it was reported that the crystallinity is a crucial factor that affects the biological behavior (Uehiraa et al. 2013; Dorozhkin 2010; Fulmer et al. 2002). Hong et al. have demonstrated that osteoblasts exhibited a high cellular activity such as adhesion on the low-crystallinity HAP thin film (Hong et al. 2003). The gradual increase in 
the intensity of HAP peaks with increasing the $\mathrm{pH}$ value indicates further nucleation growth of the hexagonal nanocrystals.

Crystallite size was calculated for HAP powder using Scherrer's formula and reported in Table 2 . The crystallite size of the HAP crystals was 5, 15, $16 \mathrm{~nm}$ for $\mathrm{pH}$ values of 7, 9 and 12, respectively, while in the case of brushite

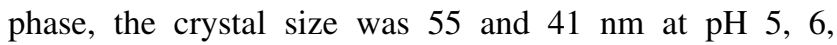
respectively. The lattice parameters for HAP were $a=9.399 \AA$ and $c=6.890 \AA$ at $\mathrm{pH}=7$. The unit cell volume was $527.19(\AA)^{3}, 527.44(\AA)^{3}$ and $526.249(\AA)^{3}$ for the $\mathrm{pH}$ values 7,9 and 12 , respectively, which agree well with that reported with ICDD card no. 04-007-2837. The theoretical density $D_{x}$ was determined using the formula:

$D_{x}=\frac{Z M}{N V}$

where $M$ is the molecular weight of the sample, $N$ is Avogadro's number, $Z$ is the number of molecules per unit cell and $V$ is the unit cell volume calculated from XRD data (Ahmed et al. 2003; Cullity 1978).

The results in Table 2 show that the above investigated samples possess a considerable amount of apparent porosity $(39-53 \%)$ as calculated from
Fig. 3 FTIR spectra of calcium phosphate: a $\mathrm{pH} 5,6, \mathbf{b} \mathrm{pH} 7,9$, 12
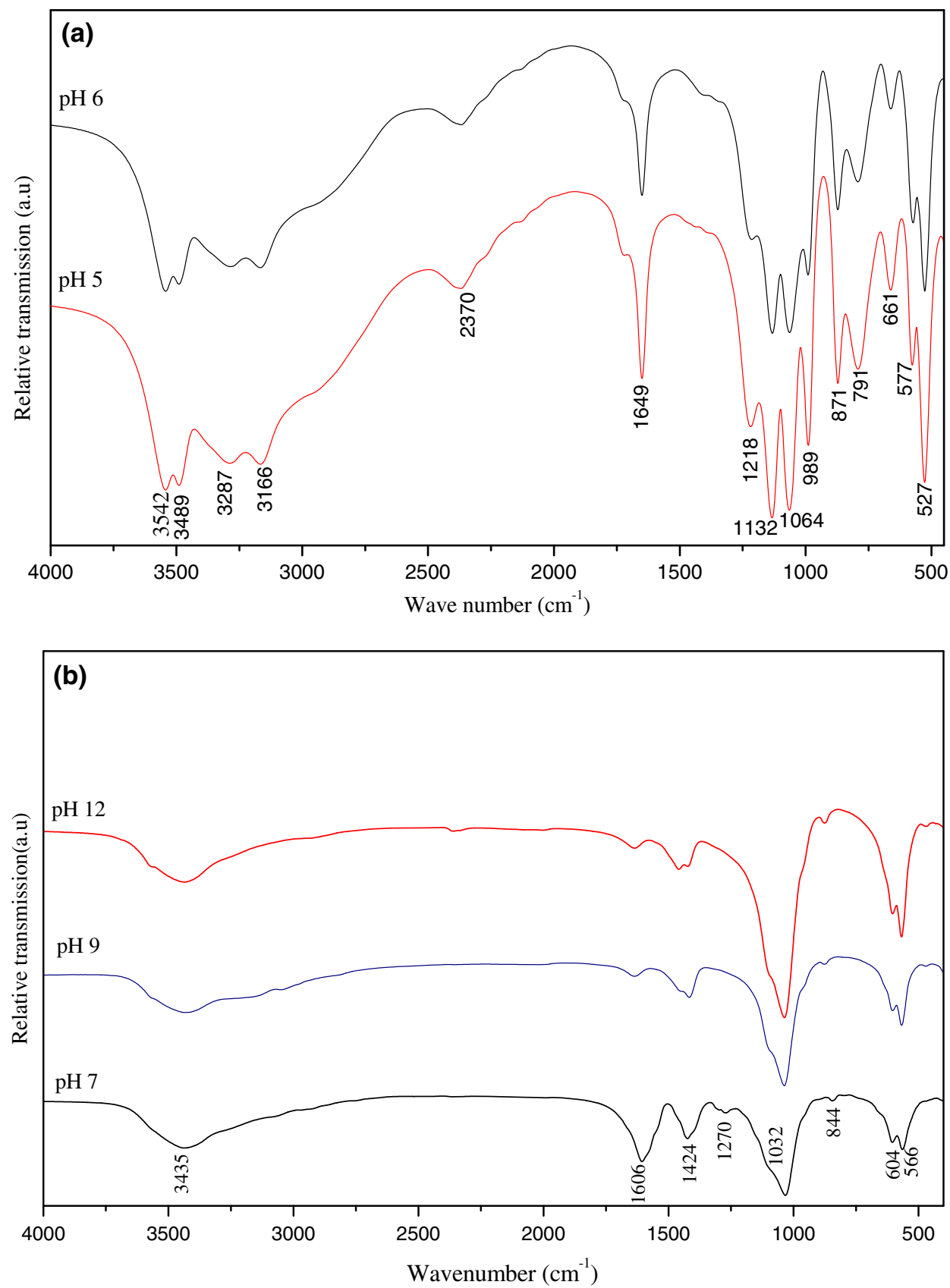
Table 3 Characteristic transmittance infrared bands of brushite and hydroxyapatite at different $\mathrm{pH}$ values

\begin{tabular}{|c|c|c|c|c|c|c|}
\hline pH 5 & pH 6 & $\begin{array}{l}\text { Assignment (Singh et al. 2010; } \\
\text { Mandel and Tas 2010; Maity et al. } \\
\text { 2011) }\end{array}$ & $\mathrm{pH} 7$ & pH 9 & $\mathrm{pH} 12$ & $\begin{array}{l}\text { Assignment (Ahmed et al. 2014; } \\
\text { Markovic et al. 2011; } \\
\text { Alobeedallah et al. 2011; Morales } \\
\text { et al. 2013; Minh et al. 2013; Asep } \\
\text { and Sopyan 2009) }\end{array}$ \\
\hline 527 & 526 & $v_{4}$ of $\mathrm{P}-\mathrm{O}-\mathrm{P}$ bending & 470 & 471 & 474 & Vibration O-P-O \\
\hline 577 & 573 & $v_{4}$ of $\mathrm{P}-\mathrm{O}-\mathrm{P}$ bending & 566 & 567 & 567 & Vibration $\mathrm{O}-\mathrm{P}-\mathrm{O}$ \\
\hline 661 & 661 & Water liberation & 604 & 603 & 606 & Vibration $\mathrm{O}-\mathrm{P}-\mathrm{O}$ mode \\
\hline 791 & 791 & Water liberation & 844 & 872 & 873 & $v_{2}$ bending of $\mathrm{CO}_{3}^{2-}$ ions \\
\hline 871 & 872 & Stretching mode of $\left(\mathrm{HPO}_{4}{ }^{2-}\right)$ & $\begin{array}{l}1032 \\
1270\end{array}$ & $\begin{array}{l}1034 \\
-\end{array}$ & $\begin{array}{l}1036 \\
-\end{array}$ & $\begin{array}{l}v_{3} \text { vibration of } \mathrm{PO}_{4}{ }^{3-} \text { ions } \\
\text { Confirm } \mathrm{CO}_{3}{ }^{2-}\end{array}$ \\
\hline 989 & 990 & $v_{1}$ stretching vibration of $\mathrm{PO}_{4}{ }^{3-}$ & 1424 & 1420 & 1421 & $v_{3}$ stretching of $\mathrm{CO}_{3}{ }^{2-}$ ions \\
\hline 1064 & 1063 & $v_{3}(\mathrm{P}-\mathrm{O})$ Stretching of the $\mathrm{PO}_{4}{ }^{3-}$ group & - & 1458 & 1460 & \\
\hline 1132 & 1131 & $v_{6}^{\prime}$ and $v_{6}^{\prime \prime}$ of $\mathrm{HPO}_{4}^{2-}$ group & & & & \\
\hline 1218 & 1215 & Bending $(\mathrm{O}-\mathrm{H})$ in $\mathrm{HPO}_{4}{ }^{2-}$ group & 1606 & 1640 & 1632 & Absorbed water \\
\hline 1649 & 1651 & Bending mode of $\mathrm{H}_{2} \mathrm{O}$ & - & 2359 & 2360 & Absorbed water \\
\hline 2370 & 2370 & Overtone or combination band & & & & \\
\hline 3166 & 3164 & $(\mathrm{O}-\mathrm{H})$ stretching of water & 3435 & 3435 & 3433 & $\mathrm{O}-\mathrm{H}$ stretching \\
\hline 3287 & 3285 & & & & & \\
\hline 3489 & 3486 & Stretching of water $\left[v_{\mathrm{s}}(\mathrm{O}-\mathrm{H})\right]$ & & & & \\
\hline 3542 & 3542 & & & & & \\
\hline
\end{tabular}
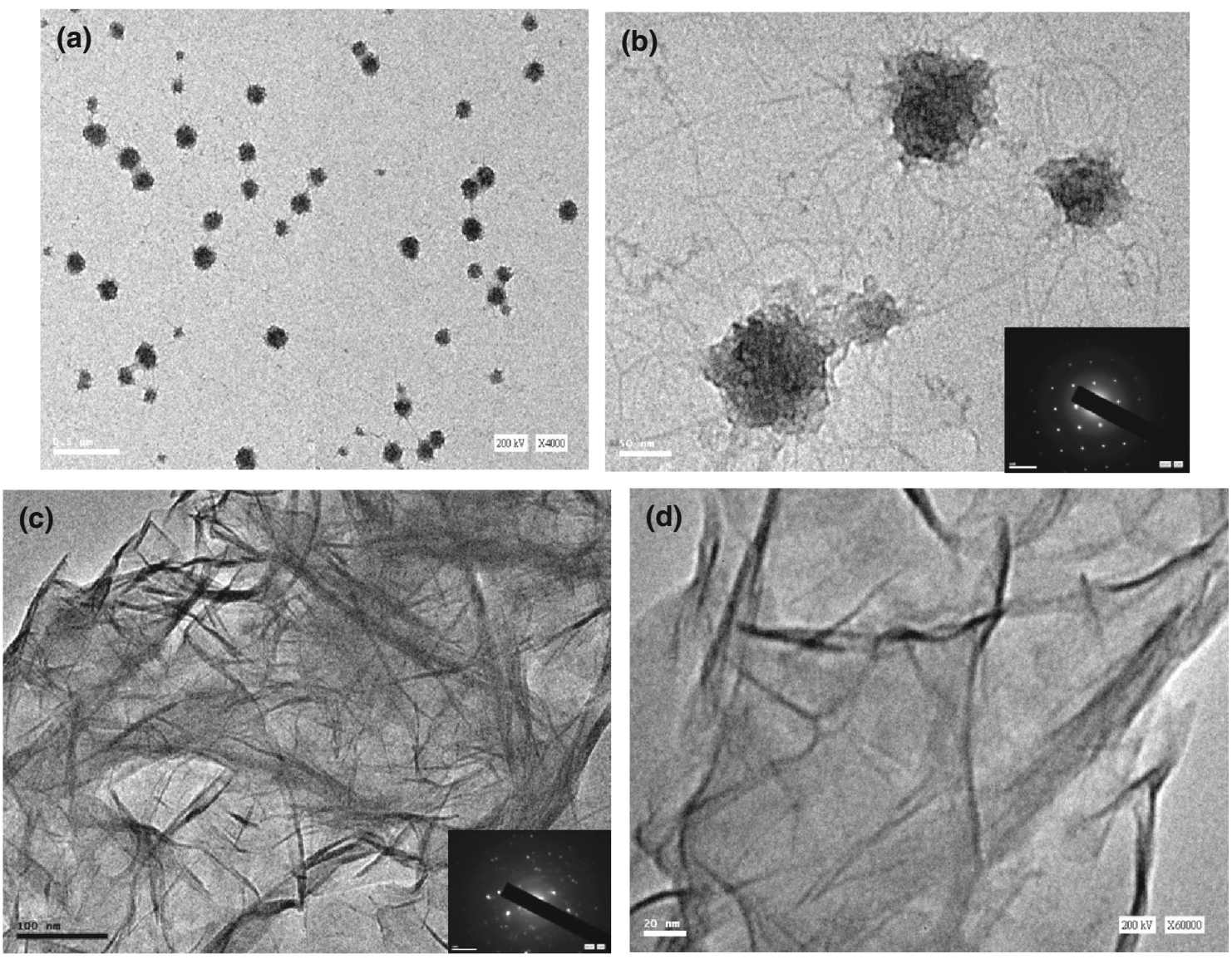

Fig. 4 TEM micrographs of brushite phase: a, b pH 5, c, d pH 6 
$P=\left(1-\frac{D}{D_{x}}\right) \times 100 \%$

where $P$ is the porosity, and $D$ and $D_{x}$ are the experimental and theoretical densities, respectively (Ahmed et al. 2003).

\section{FTIR analysis}

The structure of the samples prepared at $\mathrm{pH}$ values of 5 and 6 was investigated by FTIR spectra, as shown in Fig. 3a and presented in Table 3. From the figure, there is a neglected shift between $\mathrm{pH} 5$ and 6 . The absorption bands at $661-527$ and $1218-989 \mathrm{~cm}^{-1}$ are due to $v_{4}$ bending vibration of $\mathrm{P}-\mathrm{O}-\mathrm{P}$ mode. The vibrations at 871 and $791 \mathrm{~cm}^{-1}$ are attributed to the $\mathrm{P}-\mathrm{O}-\mathrm{H}$ vibrations for inorganic Ca-P component (Mandel and Tas 2010). The four bands, $871,989,1064 \mathrm{~cm}^{-1}$ and $1132 \mathrm{~cm}^{-1}$ are originating to the $\left(\mathrm{HPO}_{4}{ }^{2-}\right)$ stretching in both dicalcium phosphates, i.e.; monotite (DCPA) and brushite. A band at $989 \mathrm{~cm}^{-1}$ is assigned from the $\mathrm{P}-\mathrm{O}(\mathrm{H})$ symmetric stretching vibration of $\mathrm{PO}_{4}{ }^{3-}$ group (Singh et al. 2010;
Maity et al. 2011). Moreover, band near to $1064 \mathrm{~cm}^{-1}$ is reffered to the $v_{3}$ stretching mode of the $\mathrm{PO}_{4}{ }^{3-}$ group. A band around $1132 \mathrm{~cm}^{-1}$ was attributed to the $v^{\prime}{ }_{6}$ and $v^{\prime \prime}{ }_{6}$ of $\mathrm{HPO}_{4}{ }^{2-}$ ions in brushite (Maity et al. 2011).

Further investigation of the FTIR spectra revealed that the band at $1649 \mathrm{~cm}^{-1}$ was ascribed to the bending mode of $\mathrm{H}_{2} \mathrm{O}$. The bands at $3166,3287,3489$ and $3542 \mathrm{~cm}^{-1}$ corresponded to stretching vibration of water $\left[v_{\mathrm{s}}(\mathrm{O}-\mathrm{H})\right]$ (Singh et al. 2010; Ahmed et al. 2014). The bands between 3000 and $3600 \mathrm{~cm}^{-1}$ show the presence of DCPD but not in its anhydrous form DCPA (Singh et al. 2010; Zou et al. 2012).

In the spectrum shown in Fig. $3 \mathrm{~b}$ for the samples prepared at $\mathrm{pH}(7,9,12)$, the absorption bands at 3435 and $1606 \mathrm{~cm}^{-1}$ were assigned to the absorbed water (Markovic et al. 2011). The bands at 1424 and $844 \mathrm{~cm}^{-1}$ were attributed to the vibrations of $\mathrm{CO}_{3}{ }^{2-}$ groups absorbed from the ambient atmosphere (Alobeedallah et al. 2011). The presence of carbonate results from the ambient $\mathrm{CO}_{2}$ dissolved during the crystallization process, whereas HAP crystals are very susceptible to $\mathrm{CO}_{2}$. It is observable that all
Fig. 5 TEM micrographs of hydroxyapatite phase: a $\mathrm{pH} 7$, b, c $\mathrm{pH} 9, \mathbf{d} \mathrm{pH} 12$
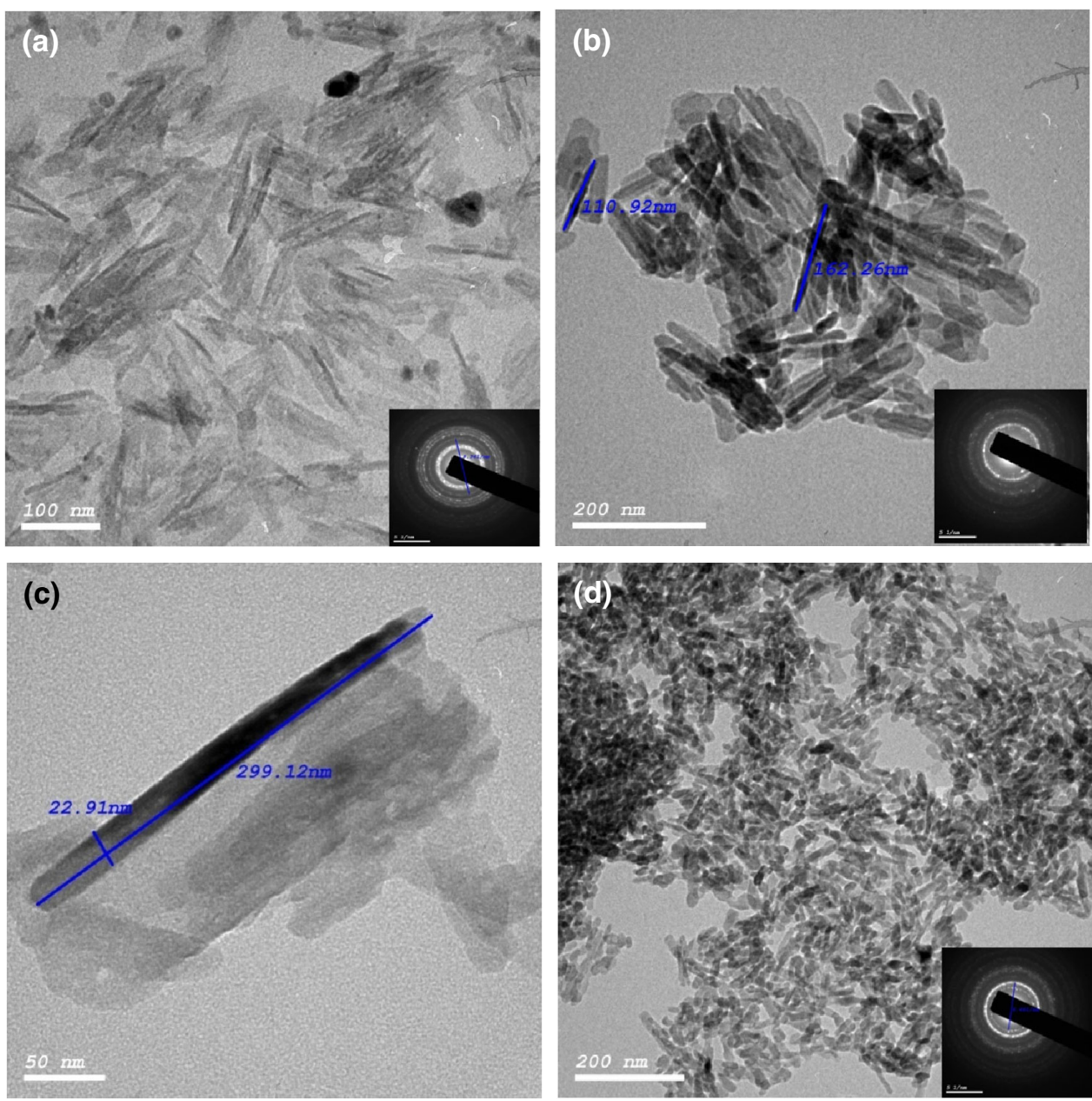
samples are classified as B-type (where $\mathrm{CO}_{3}{ }^{2-}$ substitutes phosphate position) (Ahmed et al. 2014). It should be mentioned that carbonate substitution has a critical role in the crystal structure, stability and biological activity (Morales et al. 2013; Minh et al. 2013).

The appearance of a band at $1270 \mathrm{~cm}^{-1}$, where $\mathrm{CO}_{3}{ }^{2-}$ possibly replaces $\mathrm{PO}_{4}^{3-}$, confirms the identity of carbonate (Asep and Sopyan 2009). The characteristic bands of $\mathrm{PO}_{4}{ }^{3-}$ appeared at 566, 604 and $1032 \mathrm{~cm}^{-1}$ where the bands at 566 and $604 \mathrm{~cm}^{-1}$ were assigned to the vibration of the O-P-O mode (Markovic et al. 2011). It is observed that the intensities of the bands were increased by increasing the $\mathrm{pH}$ value, as a result of the improvement of the crystallinity of the investigated samples. These results are also in good agreement with those mentioned in XRD results Fig. 2b. There is little shift with different $\mathrm{pH}$ values, and the assigned bands are reported in Table 3 .

\section{Microstructural and morphological features}

\section{TEM}

Figure $4 a, b$ shows the transmission electron micrograph of the brushite nanoparticles at $\mathrm{pH} 5$. The particles are formed in spherical shapes, with sizes ranging from 50 to $90 \mathrm{~nm}$. With further increase in the magnification, each particle looks like a silk ball with yarns linking between them. These silk filaments have different lengths with a diameter around 2-6 nm. TEM micrograph of brushite at $\mathrm{pH} 6$ shown in Fig. 4c, d reveals that the particles are formed in a fiber network with lengths from 100 to $150 \mathrm{~nm}$. The corresponding selected area electron diffraction SAED pattern shows that the particles are polycrystalline and have a preferred orientation. This special morphology of these samples facilitates their easy attachment to biological cells.
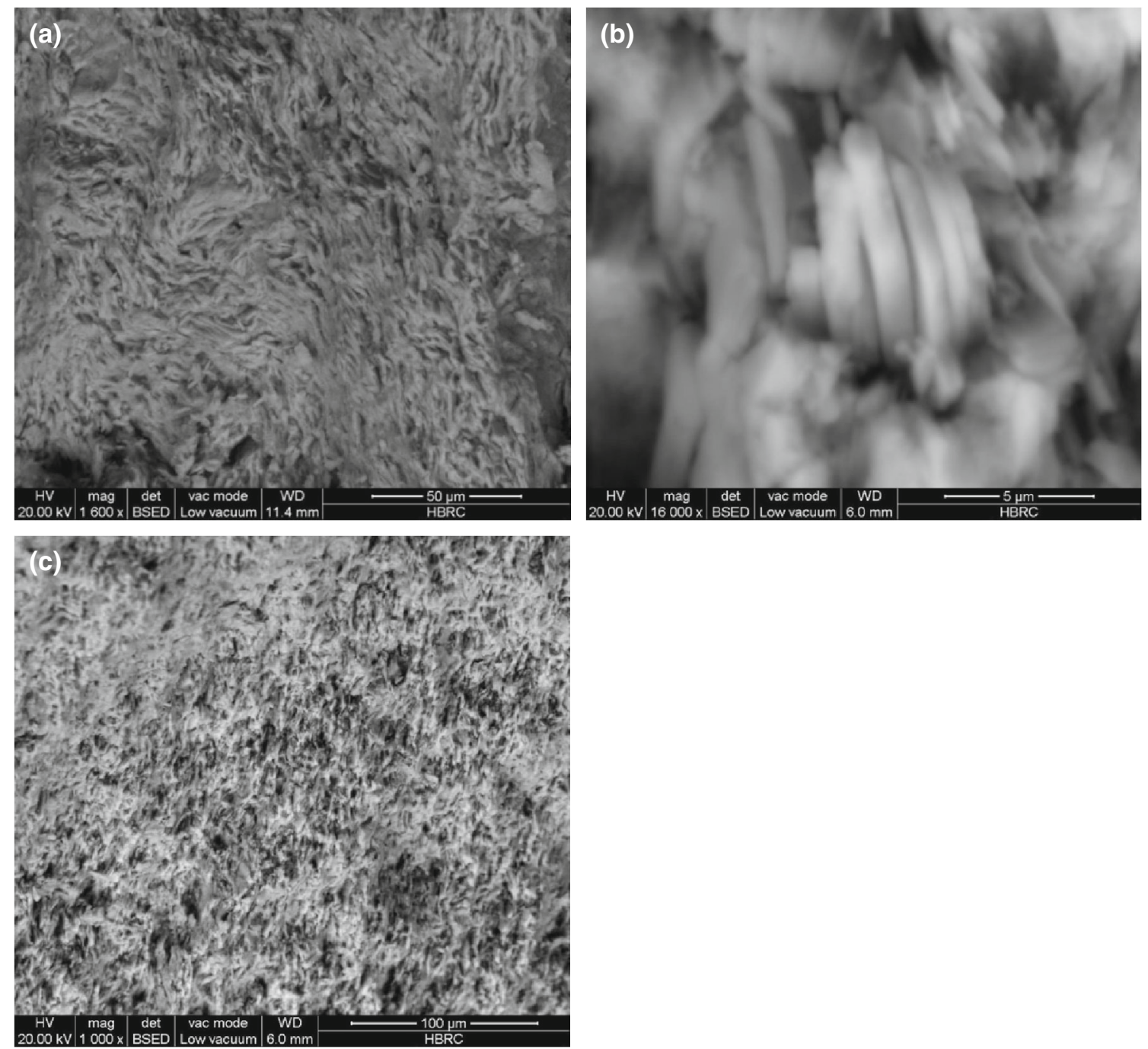

Fig. 6 SEM micrograph of brushite phase: a pH 5, b, c pH 6 
Figure 5a shows the TEM micrograph of nano-HAP at $\mathrm{pH}$ 7. The HAP nanoparticles were uniform in both morphology and size. The sample appears as needle shape crystals, with a diameter around 5-10 nm with length 150-200 nm. SAED is shown in the inset of Fig. 4a and reveals diffraction rings indicating twin crystal structure and demonstrates that the needles are polycrystalline rings with a preferred direction (100) as indicated by XRD.

TEM of HAP at $\mathrm{pH} 9$ together with the SAED was demonstrated in Fig. 5b, c. The micrograph shows nanorods with diameters ranging from 20 to $30 \mathrm{~nm}$ with a wide range of lengths starting from 200 to $300 \mathrm{~nm}$. The rod shape becomes clear and uniform by increasing the magnification with a constant aspect ratio Fig. 5c.

HAP with these dimensions $(\sim 20 \mathrm{~nm})$ resembles to the basic building blocks of enamel rods. In addition, it has been observed that HAP nanoparticles can be self-combined to form enamel-like structures in vitro and it could be adsorbed onto the enamel surface strongly. Therefore, it could be used to improve the repair of the enamel surface (Chen et al. 2005; Liu et al. 1998).

Figure 5d illustrates the TEM micrographs of HAP at $\mathrm{pH} 12$ together with SAED, which appeared as rice shape with diameters in the range of 10-20 nm in length does not exceed $60 \mathrm{~nm}$. It is clear that the particle size becomes shorter, which is attributed to the isotropic crystal growth at higher $\mathrm{pH}$ values. On the contrary, the nanoparticles synthesized at low $\mathrm{pH}$ have more complicated shapes (Liu et al. 1998).

\section{SEM}

Figure 6a illustrates the morphology of the nanobrushite sample at pH 5 which appears as homogenous surface with irregular particles, a small amount of apparent porosity. This irregularity appears on the surface as roughness,
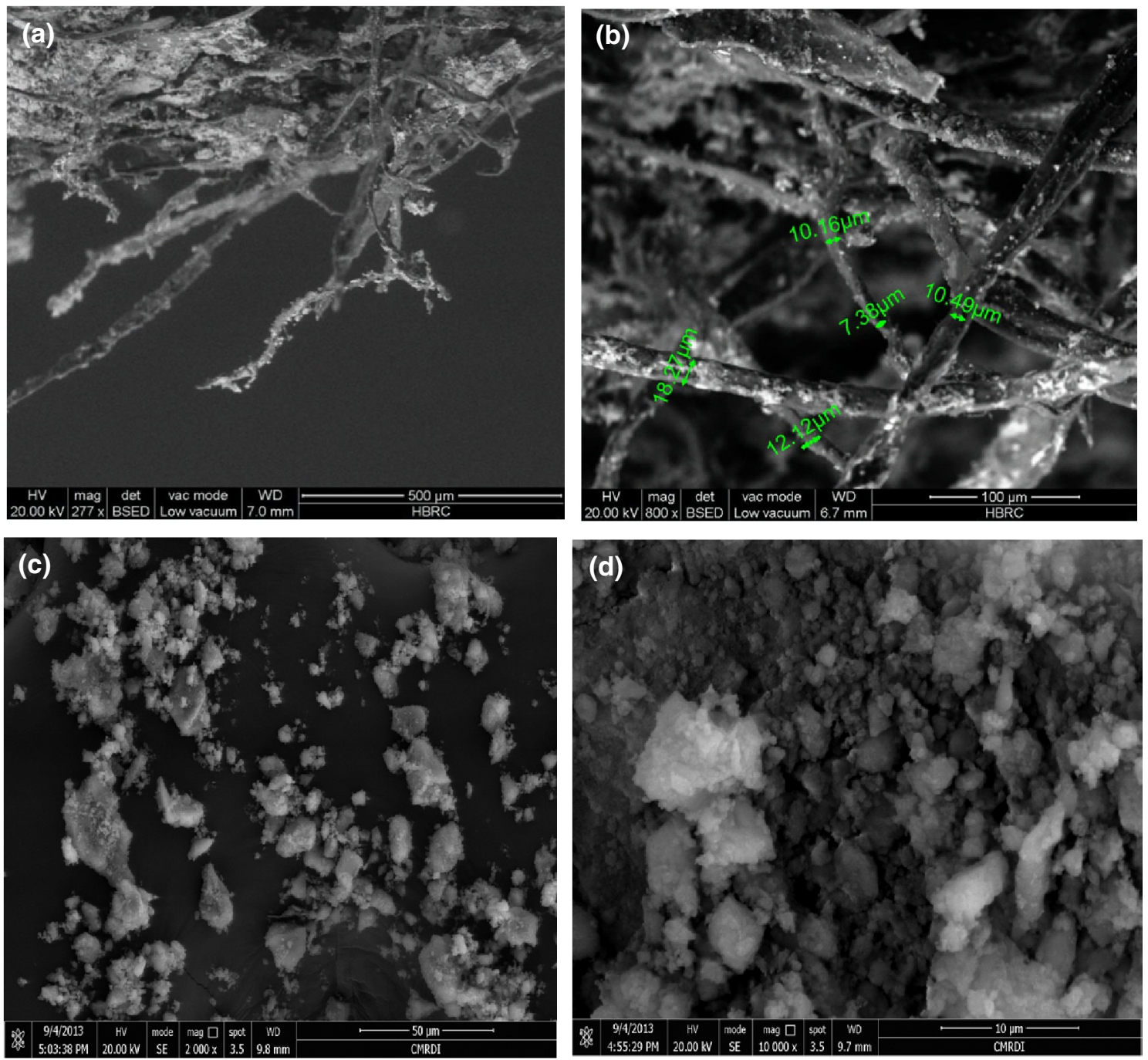

Fig. 7 SEM micrograph of hydroxyapatite phase: a, b pH 7, c, d pH 12 
which could improve the osseointegration as well as the biocompatibility leading to the positive effect on inflammatory reactions (Morales et al. 2013; Müller 2010).

For the sample prepared at $\mathrm{pH} 6$; Fig. 6b, c, the particles appeared as a bundle of fibers arranged in a certain direction with irregular pores $(24.71 \%)$ as shown in Table 2. The morphological feature of the samples with $\mathrm{pH} 7$ and 12 was demonstrated by SEM as shown in Fig. 7a-d. The nanoparticles appeared as micro fibers with diameters in ranges of 5-10 $\mu \mathrm{m}$ and length exceeding $900 \mu \mathrm{m}$ at $\mathrm{pH} 7$ as in Fig. 7a, b. Figure 7c, d reveals agglomerated grains with various sizes from 0.5 to $10 \mu \mathrm{m}$ of $\mathrm{pH} 12$.

\section{Thermal analysis}

\section{$T G A$}

Thermo-gravimetric analysis was carried out with the temperature range 30 to $1200{ }^{\circ} \mathrm{C}$ in the air at a heating rate $10{ }^{\circ} \mathrm{C} / \mathrm{min}$. Figure 8 shows the TGA of brushite at $\mathrm{pH} 5$ and $\mathrm{HAP}$ at $\mathrm{pH} 9$ and 12. For all the samples, the analysis of weight loss is observed in three stages. The first one was related to the water removal from the precipitated powders; the second and third loss ones resulted from the decomposition of organic components in the raw materials (Fulmer et al. 2002). The third stage illustrates the thermal stability of the samples from 550 to $1200{ }^{\circ} \mathrm{C}$. Total weight loss of the brushite at $\mathrm{pH} 5, \mathrm{HAP}$ at $\mathrm{pH} 9$ and 12 was 21.15 , 6.91 and $6.283 \%$, respectively, at the end of the experiment at $1200{ }^{\circ} \mathrm{C}$. This emphasizes the hypotheses that the higher $\mathrm{pH}$ values lead to higher thermal stability which is in good agreement with the reported work (Ahmed et al. 2014). The advantage of thermal analysis is to specify the working temperature range at which the bioceramics are applicable. Another benefit is to determine the exact temperature of phase transformation.

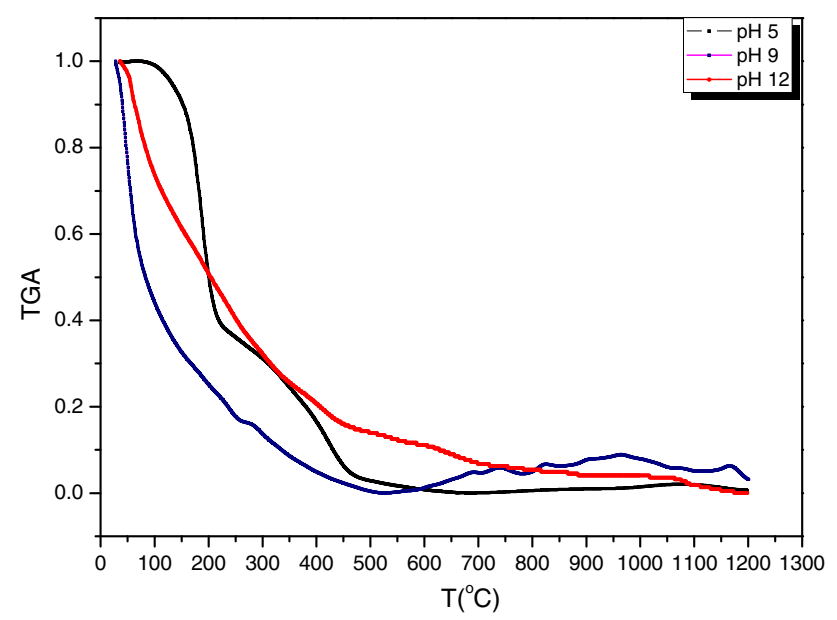

Fig. 8 TGA of brushite phase at $\mathrm{pH}$ 5, HAP at $\mathrm{pH} 9$ and 12

\section{Conclusion}

Brushite and HAP nanoparticles were successfully obtained from the homogeneous precipitation as perfect mono dispersed particles with sizes ranging from 50 to $200 \mathrm{~nm}$. The nano-HAP particles will be extensively investigated for future use in biomedical applications such as bioactive ceramics for bone substituting materials and tissue scaffold. When regulating the preparation conditions, mainly $\mathrm{pH}$ and $\mathrm{Ca} / \mathrm{P}$ ratio, different micro structures could be tailored to achieve fiber network, silk ball, short and long nanorods.

\section{Compliance with ethical standards}

Conflict of interest No conflict of interest exists.

Open Access This article is distributed under the terms of the Creative Commons Attribution 4.0 International License (http:// creativecommons.org/licenses/by/4.0/), which permits unrestricted use, distribution, and reproduction in any medium, provided you give appropriate credit to the original author(s) and the source, provide a link to the Creative Commons license, and indicate if changes were made.

\section{References}

Ahmed MA, Ateia E, El-Dek SI (2003) Rare earth doping effect on the structural and electrical properties of $\mathrm{Mg}-\mathrm{Ti}$ ferrite. Mater Lett 57:4256-4266

Ahmed MA, Okasha N, El-Dek SI (2008) Preparation and characterization of nanometric $\mathrm{Mn}$ ferrite via different methods. Nanotechnology 19:065603

Ahmed MA, Mansour SF, El-dek SI, Abd-Elwahab SM, Ahmed MK (2014) Characterization and annealing performance of calcium phosphate nanoparticles synthesized by co-precipitation method. Ceram Int 40:12807-12820

Alobeedallah H, Ellis LJ, Rohanizadeh R, Hans C, Dehghani F (2011) The preparation of nanostructured hydroxyapatite in organic solvents for clinical applications. Trends Biomater Artif Organs 25:12-19

Asep F, Sopyan L (2009) Low temperature hydrothermal synthesis of calcium phosphate ceramics: effect of excess $\mathrm{Ca}$ precursor on phase behaviour. Indian J Chem 48:1492-1500

Badraoui B, Aissa A, Bigi A, Debbabi M, Gazzano M (2009) Synthesis and characterization of $\operatorname{Sr}_{(10-\mathrm{x})} \mathrm{Cd}_{\mathrm{x}}\left(\mathrm{PO}_{4}\right)_{6} \mathrm{Y}_{2}\left(\mathrm{Y}=\mathrm{OH}^{-}\right.$and $\left.\mathrm{F}^{-}\right)$: a comparison of apatites containing two divalent cations. Mater Res Bull 44:522-530

Blair HC, Schlesinger PH, Huang CLH, Zaidi M (2007) Calcium signalling and calcium transport in bone disease. Subcell Biochem 1:539-562

Chen H, Clarkson BH, Sun K, Mansfield JF (2005) Self-assembly of synthetic hydroxyapatite nanorods into an enamel prism-like structure. J Colloid Interface Sci 288:97-103

Cullity BD (1978) Elements of X-ray diffraction, 2nd edn. AddisonWesley Publishing Company Inc., London

Dorozhkin SV (2010) Bioceramics of calcium orthophosphates. Biomaterials 31:1465-1485

Ferreira A, Oliveira C, Rocha F (2003) The different phases in the precipitation of dicalcium phosphate dihydrate. J Cryst Growth 252:599-611 
Fulmer MT, Ison IC, Hankermayer CR, Constantz BR, Ross J (2002) Measurements of the solubilities and dissolution rates of several hydroxyapatites. Biomaterials 23:751-755

Hench LL (1991) Bioceramics: from concept to clinic. J Am Ceram Soc 74:1487-1510

Hench LL (1998) Bioceramics. J Am Ceram Soc 81:1705-1728

Hong J, Kim YJ, Lee H, Lee W, Ko JS, Kim H (2003) Osteoblastic cell response to thin film of poorly crystalline calcium phosphate apatite formed at low temperatures. Biomaterials 24:2977-2984

Jadalannagari S, More S, Kowshik M, Ramanan SR (2011) Low temperature synthesis of hydroxyapatite nano-rods by a modified sol-gel technique. Mater Sci Eng C 31:1534-1538

Kundu B, Soundrapandian C, Nandi SK, Mukherjee P, Dandapat N, Roy S, Datta BK, Mandal TK, Basu D, Bhattacharya RN (2010a) Development of new localized drug delivery system based on ceftriaxone-sulbactam composite drug impregnated porous hydroxyapatite: a systematic approach for in vitro and in vivo animal trial. Pharm Res 27:1659-1676

Kundu B, Lemos A, Soundrapandian C, Sen PS, Datta S, Ferreira JM, Basu D (2010b) Development of porous HAp and $\beta$-TCP scaffolds by starch consolidation with foaming method and drugchitosan bilayered scaffold based drug delivery system. J Mater Sci Mater Med 21:2955-2969

Liu Q, de Wijn JR, de Groot K, Blitterswijk CAV (1998) Surface modification of nano-apatite by grafting organic polymer. Biomaterials 19:1067-1072

Maity JP, Lin TJ, Cheng HH, Chen C, Reddy AS, Atla SB, Chang Y, Chen H, Chen C (2011) Synthesis of brushite particles in reverse micro emulsions of the biosurfactant surfactin. Int $\mathrm{J}$ Mol Sci 12:3821-3830

Mandel S, Tas AC (2010) Brushite (CaHPO4.2H2O) to octacalcium phosphate (Ca8(HPO4)2(PO4)4.5H2O) transformation in DMEM solutions at $36.5^{\circ} \mathrm{C}$. Mater Sci Eng C 30:245-254

Markovic S, Veselinovic L, Lukic MJ, Karanovic L, Bracko I, Ignjatovic N, Uskokovic D (2011) Synthetical bone-like and biological hydroxyapatites: a comparative study of crystal structure and morphology. Biomed Mater 6:045005

Minh DP, Tran ND, Nzihou A, Sharrock P (2013) Carbonatecontaining apatite (CAP) synthesis under moderate conditions starting from calcium carbonate and orthophosphoric acid. Mater Sci Eng C 33:2971-2980

Morales JG, Iafisco M, López JMD, Sarda S, Drouet C (2013) Progress on the preparation of nanocrystalline apatites and surface characterization: overview of fundamental and applied aspects. Prog Cryst Growth Charact Mater 59:1-46
Müller B (2010) Tailoring biocompatibility: benefitting patients. Mater Today 13:58

Navarro M, Michiardi A, Castano O, Planell J (2008) Biomaterials in orthopaedics. J R Soc Interface 5:1137-1158

Nilsson M, Fernandez E, Sarda S, Lidgren L, Planell JA (2002) Characterization of novel calcium phosphate/sulphate bone cement. J Biomed Mater Res 61:600-607

Ohura K, Bohner M, Hardouin P, Lemaitre J, Pasquier G, Flautre B (1996) Resorption of, and bone formation from, new $\beta$ tricalcium phosphate-monocalcium phosphate cements: an in vivo study. J Biomed Mater Res 30:193-200

Oliveira C, Georgieva P, Rocha F, Ferreira A, Azevedo SF (2007) Dynamical model of brushite precipitation. J Cryst Growth 305:201-210

Pattanayak DK, Dash R, Prasad RC, Rao BT, Mohan TRR (2007) Synthesis and sintered properties evaluation of calcium phosphate ceramics. Mater Sci Eng, C 27:684-690

Peacock M (2010) Calcium metabolism in health and disease. J Am Soc 5:23-30

Ren F, Ding Y, Ge X, Lu X, Wang K, Leng Y (2012) Growth of onedimensional single-crystalline hydroxyapatite nanorods. J Cryst Growth 349:75-82

Rey C, Combes C, Drouet C, Sfihi H, Barroug A (2007) Physicochemical properties of nanocrystalline apatites: Implications for biominerals and biomaterials. Mater Sci Eng C 27:198-205

Singh S, Singh V, Aggarwal S, Mandal UK (2010) Synthesis of brushite nanoparticles at different temperatures. Chem Pap 64:491-498

Sørensen JS, Madsen HEL (2000) The influence of magnetism on precipitation of calcium phosphate. J Cryst Growth 216:399-406

Suchanek W, Yoshimura M (1997) Hydroxyapatite ceramics with selected sintering additives. Biomaterials 13:923-933

Tamimi F, Sheikh Z, Barralet J (2012) Dicalcium phosphate cements: brushite and monetite. Acta Biomater 8:474-487

Tas AC (2000) Synthesis of biomimetic Ca-hydroxyapatite powders at $37^{\circ} \mathrm{C}$ in synthetic body fluids. Biomaterials $21: 1429-1438$

Uehiraa M, Okadab M, Takedab S, Matsumoto N (2013) Preparation and characterization of low-crystallized hydroxyapatite nano porous plates and granules. Appl Surf Sci 287:195-202

Viswanath B, Ravishankar N (2008) Controlled synthesis of plateshaped hydroxyapatite and implications for the morphology of the apatite phase in bone. Biomaterials 29:4855-4863

Zou Z, Lin K, Chen L, Chang J (2012) Ultrafast synthesis and characterization of carbonated hydroxyapatite nanopowders via sonochemistry-assisted microwave process. Ultrason Sonochem 19:1174-1179 